\title{
Prevalência de Tripanosoma vivax em bovinos no município de Patos de Minas/MG
}

Pedro Henrique Vieira Germano $0^{[a]}$, Gertrud Elisa Campos Edler ${ }^{[b]}$, Alex André da Silva ${ }^{[a]}$, Luis Oliveira Lopes ${ }^{[a]}$

\footnotetext{
[a] Curso de Medicina Veterinária, Centro Universitário de Patos de Minas (UNIPAM), Patos de Minas, MG, Brasil
}

[b] Centro Clínico Veterinário (CCV), Centro Universitário de Patos de Minas (UNIPAM), Patos de Minas, MG, Brasil

*Autor correspondente

e-mail: pedro.vieira11@yahoo.com.br

\section{Resumo}

A tripanossomíase bovina é uma doença de ocorrência global. 0 agente etiológico de maior relevância para bovinos é o Trypanosoma vivax (T.vivax). Registrada pela primeira vez no Brasil em 1972, no Pará, infectando búfalos, recentemente tem sido reportada em várias regiões de Minas Gerais. 0 objetivo do presente trabalho foi fazer um levantamento soroepidemiológico da tripanossomíase bovina na região de Patos de Minas. Foram avaliadas 101 amostras de soro sanguíneo de bovinos provenientes de três rebanhos, sendo duas propriedades leiteiras - onde foram coletadas amostras de todas as vacas em lactação, da raça Holandesa e Girolando, com diferentes graus de sangue, primíparas e /ou pluríparas - e uma propriedade de corte com 10 novilhas da raça Nelore prenhas, as quais foram analisadas pelo teste sorológico da Reação de Imunofluorescência Indireta (RIFI). As fazendas avaliadas adotam o sistema de criação semi-intensivo, onde os animais recebem uma dieta balanceada composta por silagem de milho e concentrado, fornecida de acordo com a produção de leite, além de uma suplementação mineral e água ad libitum. Seguem, também, um calendário sanitário proposto pelo médico veterinário responsável, o qual inclui as vacinações obrigatórias contra febre aftosa e brucelose e as vacinas reprodutivas contra rinotraqueíte infecciosa bovina (IBR), diarreia viral bovina (BVD) e leptospirose, além de vermifugações com alternância de princípios ativos dos produtos. As fazendas de exploração leiteira utilizam ocitocina no momento da ordenha em alguns animais, não sendo realizada frequentemente a troca de agulhas. Das amostras testadas, 63\% (64/101) foram reagentes para anticorpos anti-T. vivax; dessas, 36\% (23) apresentaram títulos de 80 e 160, e 25\% (16) e $3 \%$ (2) apresentaram títulos de 320 e 640, respectivamente. Os resultados encontrados neste estudo foram superiores aos encontrados em pesquisas anteriores, evidenciando uma maior disseminação da doença no estado. Um ponto a ser considerado para o aumento desta doença é a reutilização da mesma agulha em 
diversos animais, sendo as fômites fator importante na transmissão de T. vivax, pois tripomastigotas são diretamente transferidas de um animal para outro. Trata-se do primeiro inquérito sorológico para detecção de anticorpos contra T.vivax em bovinos na região de Patos de Minas, uma importante bacia leiteira do país e um grande polo de comercialização e transporte de gado. Diante dos resultados, conclui-se que a prevalência da tripanossomíase em Patos de Minas é alta e que medidas profiláticas devem ser implantadas na região para evitar a disseminação da doença. 